Western University

Scholarship@Western

$9-2016$

\title{
CEO Power, Corporate Social Responsibility, and Firm Value: A Test of Agency Theory
}

Zhichuan Li

Follow this and additional works at: https://ir.lib.uwo.ca/iveypub

Part of the Business Law, Public Responsibility, and Ethics Commons, and the Corporate Finance Commons

Citation of this paper:

Li, Zhichuan, "CEO Power, Corporate Social Responsibility, and Firm Value: A Test of Agency Theory" (2016). Business Publications. 36.

https://ir.lib.uwo.ca/iveypub/36 
CEO Power, Corporate Social Responsibility, and Firm Value:

\title{
A Test of Agency Theory
}

\author{
Frank Li \\ Ivey Business School \\ University of Western Ontario \\ fli@ivey.ca
}

Tao Li

Department of Economics

University of Western Ontario

tli282@uwo.ca

\author{
Dylan Minor \\ Kellogg School of Management \\ Northwestern University \\ d-minor@kellogg.northwestern.edu
}

May 30, 2015 
CEO Power, Corporate Social Responsibility, and Firm Value:

A Test of Agency Theory

\begin{abstract}
This study explores whether firms with powerful CEOs tend to invest (more) in corporate social responsibility (CSR) activities as the over-investment hypothesis based on classical agency theory predicts. In addition, this paper tests an alternative hypothesis that if CSR investment is indeed an agency cost like the over-investment hypothesis suggests, then those activities may destroy firm value. Using CEO pay slice (Bebchuck, Cremers, and Peyer, 2011), CEO tenure, and CEO duality to measure CEO power, we show that CEO power is negatively correlated with firm's choice to engage in CSR and with the level of CSR activities in the firm. Furthermore, our results suggest that CSR activities are in fact value-enhancing in that as firms engage in more CSR activities their value increases.
\end{abstract}

Key words: Corporate Social Responsibility, CSR, CEO power, CEO Pay Slice, CEO Tenure, CEO Duality, Agency Theory, Firm value, Tobin's Q 


\section{Introduction}

The Chief Executive Officer (CEO) is arguably a public firm's most powerful figure. There has been a vast amount of literature that explores the relationship between CEO power and firm's performance (Adams, 2005; Core et al., 1999; Daily et al., 1997). But rarely has it focused on the interaction of a firm's social performance and the CEO's power. In some firms, the CEO makes most of the decisions including the ones related to the firm's social performance and image. To fill the void, this paper explores the empirical relation between a firm's social performance and the CEO's power. In financial economics and corporate finance, a most common measure of a firm's social performance is its engagement of corporate social responsibility (CSR) and the level of CSR activities in which it engages. Unlike CEO power and CSR, the impact of CSR on firm value has been studied extensively. Gregory et al. (2014) explored the risk reducing effects of CSR and the implications for financial measures of performance. Servaes and Tamayo (2013) focused on the relationship between CSR and firm value through the lens of customer awareness as proxied by advertising expenditures. Harjoto and Jo (2011) studied the impact of CSR on corporate governance and firm value. This paper attempts to examine the relation between the two to test the over-investment hypothesis based on agency theory.

Within the CSR literature, there has been a fierce debate about the CSR's role in the firm. Friedman (1997) posits that CSR is merely the selfish behaviours by firm's management to enhance his or her own public image at the cost of the firm's 
shareholders, which is the classic agency view. Similar arguments are also made by Barnea and Rubin (2010), Malmendier and Tate (2005), who provided evidence that managers, and in particular CEOs, tend to over-invest in CSR for their personal reputation building. Following those propositions, the underlying logic of this paper is that if the over-investment hypothesis is true, then we should expect a positive relationship between CEO power and CSR. In addition, since this over-investment by managers to build personal reputations is more likely to do harm rather than good to the firm's value, there should be a negative correlation between the firm's value and CSR if that hypothesis holds.

However, our findings reveal that CEO power negatively affects the firm's decision to engage in CSR. In addition, we find that the more powerful the CEOs are, the lower the level of CSR activities firms engage in, which is the exact opposite of what the over-investment hypothesis suggests. Furthermore, this paper provides evidence that CSR activities are in fact value-enhancing rather than value-destroying as the overinvestment hypothesis suggests, which is consistent with the findings from $\mathrm{Li}$ et al. (2015), Harjoto and Jo (2011).

This paper makes one important contribution to the financial economics and corporate finance literature. Although a fair amount of researches have been completed on the empirical relationship between corporate governance and CSR (Harjoto and Jo, 2011; Jamali et al., 2008) or between the management team's power and CSR (Li et al., 2015), the relation between CEO, arguably the most powerful figure in a public firm, and 
CSR seems overlooked. Thus, in order to fill that gap, this paper examines that relation and provides important insight into how powerful CEOs affect firms' decisions in engaging in CSR activities and additional evidence against the notion of CSR as an agency cost.

\section{Literature Review and Hypotheses}

Based on Jensen and Meckling's (1976) agency theory, Barnea and Rubin (2010) consider CSR engagement as a principal-agent relation between managers and shareholders, and argue that managers have an interest in over-investing in CSR in order to obtain private benefits of building reputation as good social citizens, possibly at a cost to shareholders. On the other hand, Harjoto and Jo (2011) provides evidence supporting the conflict resolution view which states that managers engage in CSR to resolve the conflicts among various stakeholders. Despite the ongoing debate among scholars and practitioners regarding these two competing hypotheses, few definitive conclusions can be drawn and the literature remains divided (see Griffin and Mahon, 1997; Orlitsky et al., 2003; Margolis et al., 2009).

Li et al. (2015) use proprietary hand-collected compensation contract data to examine the possible factors that predict the existence of compensation incentives tied to social performance outcomes. Their findings reveal that firms with better corporate governance, measured by the number of large institutional holdings and the degree of board independence, are more likely to offer executive compensation contracts that 
contain incentives for CSR, which suggests CSR activities are likely to provide at least some form of economic benefit for firms.

Almeida et al. (2005) looks at the impact of powerful CEOs on corporate performance. Using dummy variables for whether the CEO is the founder, whether the CEO is the only insider on the board, and whether the CEO is also chairman of the board as measures of CEO power, they find that when the CEO has more decision making power firm performance is more variable. In addition, their study indicates that powerful CEOs are not only associated with firms with the worst performance, but also those with the best performance.

Phan and Hill (1991) look at the relationship between CEOs' compensation packages and CEO tenure. Their empirical tests suggest that as CEOs' company tenures become longer, CEOs' compensation packages reflect their preferences more. They also find that the relationship between CEO pay and stock returns weakens with tenure.

Among the sparse literature that looks at CEO power and CSR, Jiraporn and Chintrakarn (2013) uses Bebchuck, Cremers, and Peyer's (2011) CEO pay slice (CPS) as a proxy for CEO power and explore how powerful CEOs view investments in CSR. Their findings are twofold. The first is that when the CEO is relatively less powerful, an increase in CEO power leads to more CSR engagement. However, as the CEO becomes substantially more powerful, he is more entrenched and no longer invests more in CSR. Furthermore, they propose a threshold beyond which more powerful CEOs significantly reduce CSR investments. 
In this paper, following Jiraporn and Chintrakarn (2013) we also use Bebchuck, Cremers, and Peyer's (2011) CPS as a proxy to CEO power. Aside from CPS, we also use dummy variables for whether the CEO is chairman of the board to measure CEO power following Almeida et al. (2005). Instead of focusing on how CEOs view CSR investments like Jiraporn and Chintrakarn (2013), we investigate if CSR is truly a mechanism for CEOs to build their personal reputations as the over-investment hypothesis suggests. This is particularly interesting because in many cases, as the face of the firm, there is more incentive for the CEO than any other executive to invest in CSR to improve his or her public image. Gines-Ross (2000) finds that CEO reputation is not only important for the CEO's personal well-being, it is more crucial for a firm's success overall. Milbourn (2000) develops a model that shows a positive and economically meaningful relationship between stock-based compensation and CEO reputation. In addition to compensation, as reputation improves a CEO will enjoy better outside career opportunities and greater negotiation power. Among the many channels CEOs might utilize, corporate social responsibility activities may be the most direct and the most effective for their reputation building. Thus it is worthwhile to explore if CSR is truly employed by CEOs for personal gains.

H1a: If the over-investment theory is true, the greater the CEO power the more likely a firm will engage in CSR. And the greater the CEO power, the level of CSR engagement will increase as well. 
$\mathrm{H} 1 \mathrm{~b}$ : If the over-investment theory is not true, either greater CEO power will predict smaller likelihood of engagement in CSR or the choice of engaging in CSR is not related to CEO power. And the greater the CEO power, the level of CSR engagement will decrease.

Although embracing responsibility for corporate actions, CSR has ambiguous effects on the firm value. There are two existing competing theoretical frameworks on the relationship between CSR and firm value. On the one hand, some have argued for a negative relationship due to increased costs associated with higher levels of CSR, which would put the firm at an economic disadvantage. These added costs might include things such as extensive charitable contributions, promoting community development plans, and establishing environmental protection procedures. On the other hand, some argue for a positive relationship due to improved employee satisfaction and customer goodwill. They also believe social responsibility may improve relationship with bankers, investors, and government officials which in turn improves the firm's access to sources of capital. Empirical research has yielded mixed results regarding this relationship.

Early work by McGuire et al. (1988) analyzed the relationship between perceptions of firm CSR and measures of firm financial performance. The paper used Fortune magazine's annual ratings of corporate reputations based on survey results from over 8000 executives, outside directors, and corporate analysts. Accounting based performance measures used in the regression on CSR included return on assets, total assets, sales growth, debt-to-assets, and revenue growth among others. Their results 
suggested that firms with low CSR ratings experienced lower return on assets and stock market returns. Additionally, prior accounting performance tended to be a better predictor of future CSR levels than subsequent performance. The authors noted that one major shortcoming in their research was the lack of a reliable measure of CSR at the time.

Tsoutsoura (2004) also examined the relationship between KLD scores as a proxy for CSR and measures of firm financial performance in her applied financial project. The study used data from a 5-year period (1996 to 2000) and included most S\&P 500 firms. This paper used return on assets, return on equity, and return on sales to regress on KLD scores while controlling for firm size and industry. Her findings revealed that, in all cases, all variables are significant and there is a positive relationship between CSR and profitability.

Jo and Harjoto (2011) investigated the effects of the internal and external corporate governance and monitoring mechanisms on the choice of CSR. After correcting for endogeneity and simultaneity issues, the study found that CSR is positively associated with the corporate governance and monitoring mechanisms, and positively influences firm value measured by Tobin's Q. Moreover, the authors noted that CSR activities that address internal social enhance firm value more than other CSR subcategories for broader external social enhancement.

Another study of Jo and Harjoto (2012) examined the causal relationship between CSR and firm characteristics. Employing a large and extensive US sample, the 
authors find that while the lag of CSR does not affect corporate governance, the lag of corporate governance positively affects CSR. In addition, based on the stakeholder theory and agency theory, the study examines the causal relationship between CSR and corporate financial performance. The findings show that CSR has a positive relationship with corporate financial performance, which supports the conflict resolution hypothesis based on stakeholder theory, but not the CSR over-investment argument based on agency theory.

McWilliams and Siegel (2001) demonstrate a particular flaw among the existing econometric studies of the relationship between CSR and firm financial performance. After regressing firm financial performance on corporate social performance and other control variables, the authors realized that the model has an upward bias because it does not control for the investment in R\&D. After correcting the bias in the model, the authors found that CSR has a neutral influence on the financial performance of firms.

In light of previous researches on firm performance (value) and CSR, this paper focuses on testing the over-investment hypothesis.

$\mathrm{H} 2 \mathrm{a}$ : If the over-investment theory is true, firm value measured by Tobin's $\mathrm{Q}$ is inversely associated with the choice of CSR and level of CSR engagement.

$\mathrm{H} 2 \mathrm{~b}$ : If the over-investment theory is not true, firm value measured by Tobin's $\mathrm{Q}$ is either positively or not associated with the choice of CSR and level of CSR engagement. 


\section{Data and Summary Statistics}

\subsection{Databases}

To test our hypotheses, we used the CSR measures from the Kinder, Lydenberg, and Domini's (KLD's) Stats database. KLD's Stats database includes over 3000 companies containing various CSR characteristics. In the studies of CSR, KLD database has a uniquely important status and is widely used in prior literature (Berman et al., 1999; Chatterji et al., 2009). Our CEO data is from the Execucomp database provided by S\&P Capital IQ. Execucomp provides compensation data on CEOs at over 3000 companies. In addition, it has details on restricted stock and option awards, exercises, and previously granted awards that are still outstanding. The data stating if the CEO is also chairman of the board is from Institutional Shareholder Service (formerly RiskMetrics). We use Compustat for the financial statement data, which is also offered by S\&P Capital IQ.

The first of our final samples consists of 20,051 firm-year observations from 1998 to 2013 , representing 2,944 unique firms (unbalanced across the years). The first sample is used to compute the summary statistics on firm characteristics variables and conduct regressions in table 7 and 8.

The second consists of 16,644 firm-year observations from 1998 to 2013, representing 2,288 unique firms (unbalanced across the years). The second sample is used to conduct the regressions in Table 4. 
The third has 17,319 firm-year observations from 1998 to 2013, representing 2,329 unique firms (unbalanced across the years) and is used to conduct the regressions in Table 5.

The fourth of our final samples has 6,783 firm-year observations from 2007 to 2012, representing 1,567 distinct firms (unbalanced across the years). The fourth sample is used to conduct the regressions in Table 6.

\subsection{Test variables}

To obtain the CSR choice variable (variable CSR), we create a dummy variable equal to one if a firm has a positive score in any of the five categories in KLD database. We exclude industry-specific categories and the corporate governance category, and consider the KLD categories of community, diversity, employee relations, environment, human rights, and product. To examine the relationship between CEO power and the level of CSR activities and that between firm value and the level of CSR activities, a variable that measures the level of CSR activities in firms is needed (variable CSRLEVEL). To create the CSRLEVEL variable, we calculate the total number of KLD strengths minus concerns over the five aforementioned categories following the convention used by previous empirical studies (Griffin and Mahon, 1997; Waddock and Graves, 1997; Johnson and Greening, 1999; Mishra and Suar, 2010).

There are many valid proxies for CEO power. Bebchuck et al. (2011) argue that the CEO pay slice (CPS) captures many dimensions of CEO's role in the top management 
team. Thus it is a useful proxy for the relative power of CEO in the top team. Following their approach, we calculate CPS as the CEO's total compensation as a fraction of the combined total compensation of the top five executives (including the CEO) in a given company. While CPS can be computed for every firm-year, we restrict our sample to firm-years where the CEO was in office for the entire year. This avoids observations with artificially low CPS due to the fact that a CEO has received compensation only for part of the year. Total compensation includes salary, bonus, other annual pay, long-term incentive payouts, the total value of restricted stock granted that year, the Black-Scholes value of stock options granted that year, and all other total compensation (EXECUCOMP item TDC1).

In addition to CPS, CEO tenure and dummy variables for whether the CEO is chairman of the board are also used as proxies for CEO power. CEO tenure (variable CEOTENURE) is defined as the number of years since becoming CEO. The dummy variable (DUALITY) equals to one if the CEO is also the chairman of the board using Institutional Shareholder Service (formerly RiskMetrics) and 0 otherwise.

To measure firm value, Tobin's $Q$ is used. The Tobin's $Q$ we use is defined as the market value of equity plus the book value of assets minus the sum of book value of common equity and deferred taxes, all divided by the book value of assets. This definition is the one used by Kaplan and Zingales (1997) and subsequently also by Gompers et al. (2003) and Bebchuck et al. (2011).

\subsection{Control variables}


Endogeneity has always plagued studies in financial economics and corporate finance. To address the endogeneity problem inherent in the studies, industry fixed effects, year fixed effects, and control variables are used in this paper. Li (2014a) finds that the combination of firm fixed effects, year fixed effects, and the addition of more meaningful control variables generally works well in mitigating the endogeneity bias. The control variables used for regressions in table 5 and 6 , which examine the relationship between CSR and firm value, are only the firm characteristics variables which include leverage (variable LEVERAGE), R\&D intensity (RD), advertising intensity $(A D)$, capital expenditure ratio (CAPEX), return on assets (ROA), and firm size measured by logged sales (LOGSALES). These are the standard control variables in previous studies (Harjoto and Jo, 2012). In addition to firm characteristics variables, the regressions in table 4, which examine the relationship between CEO power and CSR, also control for CEO characteristics such as CEO total compensation as measured by tdc1 from Execucomp (CEOCOMP), CEO is also a member of the board of directors (EXECDIR), and the percentage of shares owned by CEO (SHROWN). The reason for controlling for CEO total compensation is not only that it is significantly correlated with the CPS (38.6\%) and DUALITY (9.5\%), but that it is significantly correlated with CSR (30.3\%) and CSRLEVEL (9.5\%) as well. See table 3. For the same reason, percentage of shares owned by the CEO and the dummy variable for whether the CEO is a member of the board are also used. Controlling for these two variables will help alleviate the endogeneity problem since if the CEO is the chair of the board, then he must be a member of the board, but the reverse is not necessarily true. And if the CEO owns a large percentage of shares, 
he/she has more power in influencing firm's decisions. We also use Fama-French 48 industry classification to create dummies to control for industry.

\subsection{Summary Statistics}

Table 1 presents the summary statistics. The CSRLEVEL averages -0.020 with a standard deviation of 2.038. The average CEO pay slice (CPS) is 0.389 with a standard deviation of 0.113 , which is similar to that in Bebchuck et al. (2014a). The dummy variable for whether the CEO is also chair of the board (DUALITY) averages 0.511 with a standard deviation of 0.500 . The average tenure of CEOs is 7.240 and the standard deviation 7.141. The average Tobin's $Q$ is 1.947 with a standard deviation of 1.478 .

Table 3 reports the correlations between all the key variables. The Tobin' $Q$ is positively correlated with both CSR and CSRLEVEI, which is contrary to the overinvestment theory. CPS and DUALITY are positively correlated with CSR and negatively correlated with CSRLEVEL. CEOTENURE is negatively correlated with both CSR and CSRLEVEL. A plausible explanation may be that the likelihood of firms with more powerful CEOs engaging in CSR activity is higher but the level of CSR activities in these firms tend to be lower, to the contrary of what over-investment theory suggests. The percentage of shares owned by the CEO is negatively correlated with CSR and CSRLEVEL, which is consistent with hypothesis $\mathrm{H} 1 \mathrm{~b}$ that the over-investment theory is not true. CEO total compensation is positively correlated with CSR and CSRLEVEL suggesting firms that do engage in CSR tend to pay their CEOs more than those that do not. Return on assets (ROA) is positively correlated with both CSR and CSRLEVEL, suggesting that more 
profitable firms tend to engage in CSR more, which is consistent with Harjoto and Jo (2011). Advertising intensity is also positively correlated with both CSR and CSRLEVEL. Leverage is negatively correlated with CSRLEVEL which suggests that firms with higher leverage tend to have lower level of CSR activities. Firm size, measured by logged sales, is positively correlated with both CSR and CSRLEVEL which is also consistent with findings in Harjoto and Jo (2011).

\section{Findings and Discussions}

\subsection{Univariate Tests}

To examine potential differences between firms that engage in CSR and those that do not, we compare both types of firms in table 2. In general, engagement in CSR is more common in larger firms with more powerful CEOs (measured by the CPS and DUALITY), less shares owned by CEOs, higher social performance (measured by CSRLEVEL), higher compensation paid to CEOs. Less shares owned by CEOs is contrary to the over-investment hypothesis. However, more powerful CEOs and higher compensation paid to CEOs are consistent with the over-investment theory and our hypothesis H1a. But it is worth noting that these correlations are not adjusted for industry and do not account for the correlation of the independent variables of interest with other control variables.

\subsection{Multivariate Tests}


Table 4 reports the results of the regressions of CSR and CSRLEVEL on CEO power measured by the CPS with control variables. Specifically Model 1 in table 3 regresses CSR on CPS and all control variables. The coefficient of CPS is significantly negative at the $1 \%$ level. Model 2 extends model 1 to add CSRLEVEL to the list of explanatory variables. However, the coefficient of GAP is still significantly negative at the $1 \%$ level. Model 3 regresses CSRLEVEL on CPS and all control variables. The coefficient of CPS is significantly negative at the $1 \%$ level. Model 4 extends model 3 to add CSR to the list of explanatory variables. The coefficient of CPS is still significantly negative at the $1 \%$ level. Thus, these results present strong evidence rejecting over-investment theory, in that firms with more powerful CEOs tend to engage in CSR activities less and in lower levels of CSR activities.

Table 5 reports the results from regressions of CSR and CSRLEVEL on CEOTENURE and all control variables, another proxy for CEO power. In model 1 and model 2 where CSR is the dependent variable, the coefficients of CEOTENURE are both significantly negative at the $1 \%$ level. However in model 3 and model 4 where CSRLEVEL is the dependent variable, the coefficients of CEOTENURE are not significant. One possible explanation is that CEO power affects firm's choice to engage in CSR activities but not the level of CSR activities.

Table 6 presents the results from regressions of CSR and CSRLEVEL on DUALITY and all control variables. The coefficients of DUALITY in all 4 regressions tested are 
insignificant. This may be due to the time frame of the sample used. We use data from 2007 to 2012.

Now testing the over-investment theory through Tobin's $Q$, Table 7's results unanimously support $\mathrm{H} 2 \mathrm{~b}$, and thus reject the over-investment hypothesis. Model 1 regresses CSR on Tobin's Q (Q) with all firm control variables including Fama-French 48 industry dummies and year dummies. The coefficient on $Q$ is significantly positive. Model 2 extends model 1 to add CSRLEVEL to the list of explanatory variables. The coefficient on $Q$ is still significantly positive. Model 3 regresses CSRLEVEL on $Q$ with all firm control variables including Fama-French 48 industry dummies and year dummies. The coefficient on Q is again significantly positive. In Model 4, the coefficient on Tobin's Q remains significantly positive.

In light of the possibility that it is firms that engage in CSR and choose higher level of CSR activities that tend to have higher firm value or firm performance, we conduct two additional regressions of $Q$ on CSR and $Q$ on CSRLEVEL. The results are reported in table 6. Both coefficients on CSR and CSRLEVEL are significantly positive indicating firms that engage in CSR and choose higher levels of CSR activities indeed perform better.

Taken together, the results provide strong evidence against the over-investment hypothesis based on the agency theory, suggesting the presence of CSR and the level of CSR activities are not results of agency cost but rather something that is good to the firm and value enhancing. Our results are consistent with the findings in Li (2015), 
Harjoto and Jo (2011) in that they both find evidence that CSR activities actually enhance firm value.

\section{Conclusion}

This paper sheds light on the empirical relationship between CSR investments and CEO power. The evidence rejects the over-investment hypothesis that more powerful CEOs tend to invest more in CSR activities for their own reputation building. In addition, the findings reconfirm earlier work by Li (2015), Harjoto and Jo (2011) that CSR activities are positively related to firm value and value-enhancing. This paper is unique in that it uses CEO pay slice defined by Bebchuck et al. (2011), CEO tenure, and dummy variables for whether the CEO is the chair of the board as proxies for CEO power and tests the over-investment hypothesis based on agency theory through the empirical relationship of CEO power and CSR which has been only minimally explored in the literature. 


\section{References:}

Adams, R. (2005). Powerful CEOs and Their Impact on Corporate Performance. Review of Financial Studies, 18(4), 1403-1432.

Adams, R., Almeida, H., \& Ferreira, D. (2005). Powerful CEOs and Their Impact on Corporate Performance. Review of Financial Studies, 18(4), 1403-1432.

Barnea, A., \& Rubin, A. (2010). Corporate Social Responsibility as a Conflict Between Shareholders. Journal of Business Ethics, 97(1), 71-86.

Bebchuk, L., Cremers, K., \& Peyer, U. (2011). The CEO pay slice. Journal of Financial Economics, 102(1), 199-221.

Berman, S., Wicks, A., Kotha, S., \& Jones, T. (1999). Does Stakeholder Orientation Matter? The Relationship Between Stakeholder Management Models And Firm Financial Performance. Academy of Management Journal, 42(5), 488-506.

Chatterji, A., Levine, D., \& Toffel, M. (2009). How Well Do Social Ratings Actually Measure Corporate Social Responsibility? Journal of Economics \& Management Strategy, 18(1), 125-169.

Core, J., Holthausen, R., \& Larcker, D. (1999). Corporate governance, chief executive officer compensation, and firm performance. Journal of Financial Economics, 51(3), 371-406.

Daily, C., \& Johnson, J. (1997). Sources of CEO Power and Firm Financial Performance: A Longitudinal Assessment. Journal of Management, 97-117.

Friedman, M. (1970). The Social Responsibility of Business is to increase its profits. New York Times Magazine, September 13: 32-33, 122, 124, 126.

Gaines-Ross, L. (2000). CEO Reputation: A Key Factor in Shareholder Value. Corporate Reputation Review, 3(4), 366-370.

Gompers, P., Ishii, J., \& Metrick, A. (2003). Corporate Governance And Equity Prices*. Quarterly Journal of Economics, 118(1), 107-155.

Gregory, A., Tharyan, R., \& Whittaker, J. (2014). Corporate Social Responsibility and Firm Value: Disaggregating the Effects on Cash Flow, Risk and Growth. Journal of Business Ethics, 124(4), 633-657. 
Griffin, J., \& Mahon, J. (1997). The Corporate Social Performance and Corporate Financial Performance Debate: Twenty-Five Years of Incomparable Research. Business \& Society, 36(5), 531.

Hill, C., \& Phan, P. (1991). CEO Tenure As A Determinant Of Ceo Pay. Academy of Management Journal, 34(3), 707-717.

Jamali, D., Safieddine, A., \& Rabbath, M. (2008). Corporate Governance and Corporate Social Responsibility Synergies and Interrelationships. Corporate Governance: An International Review, 16(5), 443-459.

Jensen, M., \& Meckling, W. (1976). Theory of the firm: Managerial behavior, agency costs and ownership structure. Journal of Financial Economics, 3(4), 305-360.

Jiraporn, P., \& Chintrakarn, P. (2013). How do powerful CEOs view corporate social responsibility (CSR)? An empirical note. Economics Letters, 119(3), 344-347.

Jo, H., \& Harjoto, M. (2011). Corporate Governance And Firm Value: The Impact Of Corporate Social Responsibility. Journal of Business Ethics, 103(3), 351-383.

Jo, H., \& Harjoto, M. (2012). The Causal Effect of Corporate Governance on Corporate Social Responsibility. Journal of Business Ethics, 106(1), 53-72.

Kaplan, S., \& Zingales, L. (1997). Do Investment-Cash Flow Sensitivities Provide Useful Measures of Financing Constraints? The Quarterly Journal of Economics, 112(1), 169-215.

Li, Zhichuan Frank and Hong, Bryan and Minor, Dylan, Corporate Governance and Executive Compensation for Corporate Social Responsibility (January 22, 2015). Available at SSRN: http://ssrn.com/abstract=2553963 orhttp://dx.doi.org/10.2139/ssrn.2553963

Li, Zhichuan Frank, Endogeneity in CEO Power: A Survey and Experiment (April 22, 2014a). Available at SSRN: http://ssrn.com/abstract=1785204

Li, Z.F. (2014b). Mutual monitoring and corporate governance. Journal of Banking \& Finance, 45, 255-269.

Malmendier, U., \& Tate, G. (2005). CEO Overconfidence and Corporate Investment. The Journal of Finance, 60, 2661-2700.

Margolis, Joshua D. and Elfenbein, Hillary Anger and Walsh, James P., Does it Pay to Be Good...And Does it Matter? A Meta-Analysis of the Relationship between Corporate Social and Financial Performance (March 1, 2009). Available at SSRN: http://ssrn.com/abstract=1866371 
Mcguire, J., Sundgren, A., \& Schneeweis, T. (1988). Corporate Social Responsibility And Firm Financial Performance. Academy of Management Journal, 31(4), 854-872.

Mcwilliams, A., \& Siegel, D. (2001). Corporate Social Responsibility: A Theory of the Firm Perspective. The Academy of Management Review, 26(1), 117-127.

Milbourn, T. (2003). CEO reputation and stock-based compensation. Journal of Financial Economics, 68(2), 233-262.

Mishra, S., \& Suar, D. (2010). Does Corporate Social Responsibility Influence Firm Performance of Indian Companies? Journal of Business Ethics, 95(4), 571-601.

Orlitzky, M., Schmidt, F., \& Rynes, S. (2003). Corporate Social And Financial Performance: A Meta-Analysis. Organization Studies, 24(3), 403-441.

Servaes, H., \& Tamayo, A. (2013). The Impact of Corporate Social Responsibility on Firm Value: The Role of Customer Awareness. Management Science, 59(5), 1045-1061.

Waddock, S., \& Graves, S. (1997). The Corporate Social Performance-Financial Performance Link. Strategic Management Journal, 18(4), 303-319. 
Table 1. Descriptive Statistics:

Variable

CSR

CSRLEVEL

Q

CPS

DUALITY

CEOTENURE

EXECDIR

SHROWN

CEOCOMP

ROA

RD

AD

CAPEX

LEVERAGE

LOGSALES
N

17330

17330

20051

16646

6787

17330

17330

17330

17330

20051

20051

20051

20051

20051

20051
Mean

0.577

$-0.020$

1.947

0.389

0.511

7.240

0.973

1.755

5786.8

0.028

0.396

0.012

0.427

0.187

6.943
Median

1.000

0.000

1.482

0.391

1

5.000

1.000

0.198

3617.0

0.040

0.000

0.000

0.034

0.149

6.919
Std Dev

0.494

2.038

1.478

0.113

0.500

7.141

0.161

5.170

9302.3

0.150

10.990

0.072

37.147

0.194

1.765
Minimum

0.000

$-10.000$

0.345

0

0

0.000

0.000

0.000

0.000

$-7.582$

0.000

0.000

$-0.260$

0.000

$-4.017$
Maximum

1.000

16.000

35.099

0.977

1

61.000

1.000

87.600

600347.4

2.170

900.693

8.002

5169.190

4.394

13.070 
Table 2. Univariate T-test:

This table reports the differences in means (T-statistics) between firms that engage in CSR and those that do not. ${ }^{* *}, * *, *$ denote statistical significance at the $1 \%, 5 \%$, and $10 \%$ levels, respectively.

\section{Engagement in CSR No Engagement in CSR T-Stat}

$\begin{array}{llll} & \text { Mean } & \text { Mean } & \\ \text { CSRLEVEL } & 0.405 & -0.407 & 12.73^{* * *} \\ \text { CPS } & 0.400 & 0.375 & 4.16^{* * *} \\ \text { CEOTENURE } & 7.092 & 8.571 & -3.56^{* * *} \\ \text { DUALITY } & 0.691 & 0.557 & 4.77^{* * *} \\ \text { Q } & 1.715 & 1.759 & -0.77 \\ \text { CEOCOMP } & 6542.0 & 3288.0 & 14.21^{* * *} \\ \text { EXECDIR } & 0.983 & 0.965 & 1.92^{*} \\ \text { SHROWN } & 1.305 & 2.889 & 4.73^{* * *} \\ \text { R\&D } & 0.0432 & 0.0427 & 0.05 \\ \text { AD } & 0.011 & 0.012 & -0.39 \\ \text { LEVERAGE } & 0.188 & 0.178 & 0.97 \\ \text { CAPEX } & 0.070 & 0.091 & -1.57 \\ \text { LOGSALES } & 7.880 & 6.534 & 19.85^{* * *} \\ \text { ROA } & 0.044 & 0.039 & 0.96\end{array}$

Number of

1079

422

Firms 
Table 3. Correlation Table

This table reports Correlations between key variables that we use in our paper. The first line reports the Pearson correlation coefficients, the second line denotes the Probability $>|r|$ under HO: Rho=0.

Pearson Correlation Coefficients, $\mathrm{N}=6402$

Prob > $|r|$ under HO: Rho $=0$

\begin{tabular}{|c|c|c|c|c|c|c|c|c|c|c|c|c|c|c|c|}
\hline & CSR & CSRLEVEL & $\mathbf{Q}$ & CPS & CEOTENURE & DUALITY & EXECDIR & SHROWN & CEOCOMP & ROA & RD & AD & CAPEX & LEVERAGE & LOGSALES \\
\hline \multirow[t]{2}{*}{ CSR } & 1 & 0.263 & 0.017 & 0.086 & -0.111 & 0.069 & 0.053 & -0.125 & 0.303 & 0.034 & -0.007 & 0.035 & -0.004 & 0.078 & 0.459 \\
\hline & & $<.0001$ & 0.174 & $<.0001$ & $<.0001$ & $<.0001$ & $<.0001$ & $<.0001$ & $<.0001$ & 0.007 & 0.578 & 0.005 & 0.774 & $<.0001$ & $<.0001$ \\
\hline \multirow[t]{2}{*}{ CSRLEVEL } & 0.263 & 1 & 0.099 & -0.023 & -0.017 & -0.009 & 0.030 & -0.041 & 0.095 & 0.067 & 0.045 & 0.073 & -0.035 & -0.061 & 0.068 \\
\hline & $<.0001$ & & $<.0001$ & 0.063 & 0.183 & 0.474 & 0.017 & 0.001 & $<.0001$ & $<.0001$ & 0.000 & $<.0001$ & 0.005 & $<.0001$ & $<.0001$ \\
\hline $\mathbf{Q}$ & 0.174 & $<.0001$ & & 0.087 & 0.075 & 0.002 & 0.943 & $<.0001$ & $<.0001$ & $<.0001$ & $<.0001$ & $<.0001$ & $<.0001$ & $<.0001$ & $<.0001$ \\
\hline \multirow[t]{2}{*}{ CPS } & 0.086 & -0.023 & -0.021 & 1 & -0.031 & 0.079 & 0.042 & -0.152 & 0.386 & 0.054 & -0.017 & 0.001 & -0.010 & 0.092 & 0.118 \\
\hline & $<.0001$ & 0.063 & 0.087 & & 0.014 & $<.0001$ & 0.001 & $<.0001$ & $<.0001$ & $<.0001$ & 0.179 & 0.911 & 0.445 & $<.0001$ & $<.0001$ \\
\hline CEOTENURE & -0.111 & -0.017 & 0.022 & -0.031 & 1 & 0.295 & -0.062 & 0.411 & -0.035 & 0.012 & 0.004 & -0.041 & 0.015 & -0.073 & -0.143 \\
\hline \multirow[t]{2}{*}{ DUALITY } & 0.069 & -0.009 & -0.038 & 0.079 & 0.295 & 1 & -0.074 & 0.141 & 0.095 & 0.020 & -0.048 & -0.032 & 0.030 & 0.040 & 0.128 \\
\hline & $<.0001$ & 0.474 & 0.002 & $<.0001$ & $<.0001$ & & $<.0001$ & $<.0001$ & $<.0001$ & 0.105 & 0.000 & 0.010 & 0.015 & 0.001 & $<.0001$ \\
\hline \multirow[t]{2}{*}{ EXECDIR } & 0.053 & 0.030 & 0.001 & 0.042 & -0.062 & -0.074 & 1 & -0.085 & 0.030 & 0.009 & -0.007 & -0.021 & -0.002 & -0.033 & 0.069 \\
\hline & $<.0001$ & 0.017 & 0.943 & 0.001 & $<.0001$ & $<.0001$ & & $<.0001$ & 0.016 & 0.450 & 0.584 & 0.088 & 0.868 & 0.009 & $<.0001$ \\
\hline \multirow[t]{2}{*}{ SHROWN } & -0.125 & -0.041 & 0.061 & -0.152 & 0.411 & 0.141 & -0.085 & 1 & -0.080 & 0.027 & -0.010 & 0.043 & -0.024 & -0.102 & -0.141 \\
\hline & $<.0001$ & 0.001 & $<.0001$ & $<.0001$ & $<.0001$ & $<.0001$ & $<.0001$ & & $<.0001$ & 0.033 & 0.439 & 0.001 & 0.056 & $<.0001$ & $<.0001$ \\
\hline \multirow[t]{2}{*}{ CEOCOMP } & 0.303 & 0.095 & 0.059 & 0.386 & -0.035 & 0.095 & 0.030 & -0.080 & 1 & 0.109 & 0.007 & 0.077 & 0.062 & 0.102 & 0.575 \\
\hline & $<.0001$ & $<.0001$ & $<.0001$ & $<.0001$ & 0.005 & $<.0001$ & 0.016 & $<.0001$ & & $<.0001$ & 0.588 & $<.0001$ & $<.0001$ & $<.0001$ & $<.0001$ \\
\hline ROA & 0.034 & 0.067 & 0.436 & 0.054 & 0.012 & 0.020 & 0.009 & 0.027 & 0.109 & 1 & -0.181 & 0.067 & -0.057 & -0.150 & 0.107 \\
\hline \multirow[t]{2}{*}{ RD } & -0.007 & 0.045 & 0.120 & -0.017 & 0.004 & -0.048 & -0.007 & -0.010 & 0.007 & -0.181 & 1 & -0.019 & -0.016 & -0.066 & -0.137 \\
\hline & 0.578 & 0.000 & $<.0001$ & 0.179 & 0.770 & 0.000 & 0.584 & 0.439 & 0.588 & $<.0001$ & & 0.138 & 0.209 & $<.0001$ & $<.0001$ \\
\hline \multirow[t]{2}{*}{ AD } & 0.035 & 0.073 & 0.160 & 0.001 & -0.041 & -0.032 & -0.021 & 0.043 & 0.077 & 0.067 & -0.019 & 1 & -0.086 & -0.012 & 0.015 \\
\hline & 0.005 & $<.0001$ & $<.0001$ & 0.911 & 0.001 & 0.010 & 0.088 & 0.001 & $<.0001$ & $<.0001$ & 0.138 & & $<.0001$ & 0.348 & 0.246 \\
\hline \multirow[t]{2}{*}{ CAPEX } & -0.004 & -0.035 & -0.084 & -0.010 & 0.015 & 0.030 & -0.002 & -0.024 & 0.062 & -0.057 & -0.016 & -0.086 & 1 & 0.166 & -0.033 \\
\hline & 0.774 & 0.005 & $<.0001$ & 0.445 & 0.235 & 0.015 & 0.868 & 0.056 & $<.0001$ & $<.0001$ & 0.209 & $<.0001$ & & $<.0001$ & 0.008 \\
\hline \multirow[t]{2}{*}{ LEVERAGE } & 0.078 & -0.061 & -0.174 & 0.092 & -0.073 & 0.040 & -0.033 & -0.102 & 0.102 & -0.150 & -0.066 & -0.012 & 0.166 & 1 & 0.180 \\
\hline & $<.0001$ & $<.0001$ & $<.0001$ & $<.0001$ & $<.0001$ & 0.001 & 0.009 & $<.0001$ & $<.0001$ & $<.0001$ & $<.0001$ & 0.348 & $<.0001$ & & $<.0001$ \\
\hline \multirow[t]{2}{*}{ LOGSALES } & 0.459 & 0.068 & -0.095 & 0.118 & -0.143 & 0.128 & 0.069 & -0.141 & 0.575 & 0.107 & -0.137 & 0.015 & -0.033 & 0.180 & 1 \\
\hline & $<.0001$ & $<.0001$ & $<.0001$ & $<.0001$ & $<.0001$ & $<.0001$ & $<.0001$ & $<.0001$ & $<.0001$ & $<.0001$ & $<.0001$ & 0.246 & 0.008 & $<.0001$ & \\
\hline
\end{tabular}


Table 4. CSR, CSRLEVEL, and CPS

Results are from ordinary least squares (OLS) regression models. T-statistics are reported in parentheses. $* * *, * *, *$ denote statistical significance at the $1 \%, 5 \%$, and $10 \%$ levels, respectively.

\begin{tabular}{|c|c|c|c|c|}
\hline & Model 1 & Model 2 & Model 3 & Model 4 \\
\hline Dependent Variable & CSR & CSR & CSRLEVEL & CSRLEVEL \\
\hline CSR & & & & $\begin{array}{c}1.225^{* * *} \\
(39.37)\end{array}$ \\
\hline CSRLEVEL & & $\begin{array}{c}0.070 * * * \\
(39.37)\end{array}$ & & \\
\hline CPS & $\begin{array}{c}-0.170 * * * \\
(-4.43)\end{array}$ & $\begin{array}{c}-0.077^{* *} \\
(-2.08)\end{array}$ & $\begin{array}{c}-1.343 * * * \\
(-8.34)\end{array}$ & $\begin{array}{c}-1.135 * * * \\
(-7.36)\end{array}$ \\
\hline EXECDIR & $\begin{array}{c}0.058 * * * \\
(2.74)\end{array}$ & $\begin{array}{c}0.047^{* *} \\
(2.31)\end{array}$ & $\begin{array}{c}0.162 * \\
(1.83)\end{array}$ & $\begin{array}{l}0.091 \\
(1.07)\end{array}$ \\
\hline SHROWN & $\begin{array}{c}-0.003 * * \\
(-4.75)\end{array}$ & $\begin{array}{c}-0.003^{* *} \\
(-3.90)\end{array}$ & $\begin{array}{c}-0.010 * * * \\
(-3.48)\end{array}$ & $\begin{array}{c}-0.006 * * \\
(-2.19)\end{array}$ \\
\hline Ln(CEOCOMP) & $\begin{array}{c}0.036 * * * \\
(6.93)\end{array}$ & $\begin{array}{c}0.027 * * * \\
(5.33)\end{array}$ & $\begin{array}{c}0.136 * * * \\
(6.25)\end{array}$ & $\begin{array}{c}0.092^{* * *} \\
(4.41)\end{array}$ \\
\hline ROA & $\begin{array}{l}-0.049 \\
(-1.43)\end{array}$ & $\begin{array}{c}-0.116 * * * \\
(-3.55)\end{array}$ & $\begin{array}{c}0.964 * * * \\
(6.74)\end{array}$ & $\begin{array}{c}1.023 * * * \\
(7.49)\end{array}$ \\
\hline $\mathrm{RD}$ & $\begin{array}{c}0.026 * * * \\
(2.95)\end{array}$ & $\begin{array}{c}0.021^{* *} \\
(2.50)\end{array}$ & $\begin{array}{c}0.071^{*} \\
(1.92)\end{array}$ & $\begin{array}{l}0.039 \\
(1.11)\end{array}$ \\
\hline$A D$ & $\begin{array}{c}0.377^{* * *} \\
(2.67)\end{array}$ & $\begin{array}{l}0.209 \\
(1.55)\end{array}$ & $\begin{array}{c}2.400 * * * \\
(4.06)\end{array}$ & $\begin{array}{c}1.939 * * * \\
(3.43)\end{array}$ \\
\hline CAPEX & $\begin{array}{l}0.004 \\
(1.53)\end{array}$ & $\begin{array}{l}0.004 \\
(1.35)\end{array}$ & $\begin{array}{l}0.010 \\
(0.81)\end{array}$ & $\begin{array}{l}0.004 \\
(0.38)\end{array}$ \\
\hline LEVERAGE & $\begin{array}{c}-0.041^{* *} \\
(-1.97)\end{array}$ & $\begin{array}{l}-0.027 \\
(-1.34)\end{array}$ & $\begin{array}{c}-0.205^{* *} \\
(-2.35)\end{array}$ & $\begin{array}{c}-0.155^{*} \\
(-1.86)\end{array}$ \\
\hline LOGSALES & $\begin{array}{c}0.124 * * * \\
(38.08)\end{array}$ & $\begin{array}{c}0.124 * * * \\
(39.76)\end{array}$ & $\begin{array}{l}0.002 \\
(0.18)\end{array}$ & $\begin{array}{c}-0.150 * * * \\
(-10.99)\end{array}$ \\
\hline Intercept & $\begin{array}{c}-0.790 * * * \\
(-19.11)\end{array}$ & $\begin{array}{c}-0.848 * * * \\
(-21.43)\end{array}$ & $\begin{array}{c}0.826 * * * \\
(4.77)\end{array}$ & $\begin{array}{c}1.793 * * * \\
(10.72)\end{array}$ \\
\hline FF48 Industry & Yes & Yes & Yes & Yes \\
\hline Year Dummies & Yes & Yes & Yes & Yes \\
\hline Obs & 16644 & 16644 & 16644 & 16644 \\
\hline $\mathrm{R}^{\wedge} 2$ & $21.11 \%$ & $27.86 \%$ & $22.29 \%$ & $28.94 \%$ \\
\hline
\end{tabular}


Table 5. CSR, CSRLEVEL, and CEO TENURE

Results are from ordinary least squares (OLS) regression models. T-statistics are reported in parentheses. $* * *, * *, *$ denote statistical significance at the $1 \%, 5 \%$, and $10 \%$ levels, respectively.

\begin{tabular}{|c|c|c|c|c|}
\hline & Model 1 & Model 2 & Model 3 & Model 4 \\
\hline Dependent Variable & CSR & CSR & CSRLEVEL & CSRLEVEL \\
\hline CSR & & & & $\begin{array}{c}1.217^{* * *} \\
(40.48)\end{array}$ \\
\hline CSRLEVEL & & $\begin{array}{c}0.071 * * * \\
(40.48)\end{array}$ & & \\
\hline CEOTENURE & $\begin{array}{c}-0.002 * * * \\
(-4.18)\end{array}$ & $\begin{array}{c}-0.002 * * * \\
(-4.37)\end{array}$ & $\begin{array}{c}-0.00003 \\
(-0.02)\end{array}$ & $\begin{array}{l}0.003 \\
(1.27)\end{array}$ \\
\hline EXECDIR & $\begin{array}{c}0.046 * * \\
(2.19)\end{array}$ & $\begin{array}{c}0.039 * \\
(1.95)\end{array}$ & $\begin{array}{l}0.096 \\
(1.11)\end{array}$ & $\begin{array}{l}0.040 \\
(0.49)\end{array}$ \\
\hline SHROWN & $\begin{array}{c}-0.002 * * * \\
(-2.80)\end{array}$ & $\begin{array}{c}-0.001 * * \\
(-2.02)\end{array}$ & $\begin{array}{c}-0.009 * * * \\
(-2.95)\end{array}$ & $\begin{array}{c}-0.007^{* *} \\
(-2.22)\end{array}$ \\
\hline Ln(CEOCOMP) & $\begin{array}{c}0.013^{* * *} \\
(3.47)\end{array}$ & $\begin{array}{c}0.012 * * * \\
(3.45)\end{array}$ & $\begin{array}{l}0.009 \\
(0.58)\end{array}$ & $\begin{array}{l}-0.007 \\
(-0.46)\end{array}$ \\
\hline ROA & $\begin{array}{l}-0.043 \\
(-1.33)\end{array}$ & $\begin{array}{c}-0.108 * * * \\
(-3.50)\end{array}$ & $\begin{array}{c}0.916^{* * *} \\
(6.88)\end{array}$ & $\begin{array}{c}0.968 * * * \\
(7.60)\end{array}$ \\
\hline $\mathrm{RD}$ & $\begin{array}{c}0.026^{* * *} \\
(2.75)\end{array}$ & $\begin{array}{c}0.019 * * \\
(2.15)\end{array}$ & $\begin{array}{c}0.091^{* *} \\
(2.35)\end{array}$ & $\begin{array}{l}0.059 \\
(1.61)\end{array}$ \\
\hline$A D$ & $\begin{array}{c}0.443^{* * *} \\
(3.25)\end{array}$ & $\begin{array}{c}0.256^{* *} \\
(1.96)\end{array}$ & $\begin{array}{c}2.630 * * * \\
(4.66)\end{array}$ & $\begin{array}{c}2.090 * * * \\
(3.87)\end{array}$ \\
\hline CAPEX & $\begin{array}{c}0.005^{*} \\
(1.84)\end{array}$ & $\begin{array}{l}0.004 \\
(1.53)\end{array}$ & $\begin{array}{l}0.015 \\
(1.28)\end{array}$ & $\begin{array}{l}0.009 \\
(0.78)\end{array}$ \\
\hline LEVERAGE & $\begin{array}{c}-0.051 * * \\
(-2.54)\end{array}$ & $\begin{array}{c}-0.034^{*} \\
(-1.77)\end{array}$ & $\begin{array}{c}-0.240 * * * \\
(-2.89)\end{array}$ & $\begin{array}{c}-0.178 * * \\
(-2.24)\end{array}$ \\
\hline LOGSALES & $\begin{array}{c}0.133^{* * *} \\
(45.73)\end{array}$ & $\begin{array}{c}0.129 * * * \\
(46.54)\end{array}$ & $\begin{array}{c}0.050^{* * *} \\
(4.17)\end{array}$ & $\begin{array}{c}-0.111 * * * \\
(-9.19)\end{array}$ \\
\hline Intercept & $\begin{array}{c}-0.720 * * * \\
(-19.11)\end{array}$ & $\begin{array}{c}-0.787^{* * *} \\
(-20.46)\end{array}$ & $\begin{array}{c}0.936^{* * *} \\
(5.64)\end{array}$ & $\begin{array}{c}1.812^{* * *} \\
(11.32)\end{array}$ \\
\hline FF48 Industry & Yes & Yes & Yes & Yes \\
\hline Year Dummies & Yes & Yes & Yes & Yes \\
\hline Obs & 17319 & 17319 & 17319 & 17319 \\
\hline $\mathrm{R}^{\wedge} 2$ & $21.39 \%$ & $28.21 \%$ & $21.17 \%$ & $28.00 \%$ \\
\hline
\end{tabular}


Table 6. CSR, CSRLEVEL, and CEO DUALITY

Results are from ordinary least squares (OLS) regression models. T-statistics are reported in parentheses. $* * *, * *, *$ denote statistical significance at the $1 \%, 5 \%$, and $10 \%$ levels, respectively.

\begin{tabular}{|c|c|c|c|c|}
\hline & Model 1 & Model 2 & Model 3 & Model 4 \\
\hline Dependent Variable & CSR & CSR & CSRLEVEL & CSRLEVEL \\
\hline CSR & & & & $\begin{array}{c}1.329 * * * \\
(25.59)\end{array}$ \\
\hline CSRLEVEL & & $\begin{array}{c}0.067 * * * \\
(25.59)\end{array}$ & & \\
\hline DUALITY & $\begin{array}{l}0.010 \\
(0.93)\end{array}$ & $\begin{array}{l}0.009 \\
(0.86)\end{array}$ & $\begin{array}{l}0.018 \\
(0.38)\end{array}$ & $\begin{array}{l}0.005 \\
(0.10)\end{array}$ \\
\hline EXECDIR & $\begin{array}{l}0.022 \\
(0.70)\end{array}$ & $\begin{array}{l}0.024 \\
(0.83)\end{array}$ & $\begin{array}{l}-0.043 \\
(-0.32)\end{array}$ & $\begin{array}{l}-0.072 \\
(-0.55)\end{array}$ \\
\hline SHROWN & $\begin{array}{c}-0.005^{* * *} \\
(-4.25)\end{array}$ & $\begin{array}{c}-0.004^{* *} \\
(-3.61)\end{array}$ & $\begin{array}{c}-0.013 * * * \\
(-2.69)\end{array}$ & $\begin{array}{l}-0.007 \\
(-1.49)\end{array}$ \\
\hline Ln(CEOCOMP) & $\begin{array}{c}0.021 * * * \\
(3.63)\end{array}$ & $\begin{array}{c}0.019 * * * \\
(3.50)\end{array}$ & $\begin{array}{l}0.026 \\
(0.99)\end{array}$ & $\begin{array}{l}-0.002 \\
(-0.09)\end{array}$ \\
\hline ROA & $\begin{array}{l}-0.003 \\
(-0.05)\end{array}$ & $\begin{array}{l}-0.057 \\
(-1.03)\end{array}$ & $\begin{array}{c}0.812^{* * *} \\
(3.13)\end{array}$ & $\begin{array}{c}0.816^{* * *} \\
(3.29)\end{array}$ \\
\hline $\mathrm{RD}$ & $\begin{array}{c}0.076 * * * \\
(3.43)\end{array}$ & $\begin{array}{c}0.058^{* *} \\
(2.76)\end{array}$ & $\begin{array}{c}0.263 * * * \\
(2.66)\end{array}$ & $\begin{array}{l}0.162 * \\
(1.72)\end{array}$ \\
\hline$A D$ & $\begin{array}{l}0.353 \\
(1.60)\end{array}$ & $\begin{array}{l}0.033 \\
(0.16)\end{array}$ & $\begin{array}{c}4.794^{* * *} \\
(4.89)\end{array}$ & $\begin{array}{c}4.325^{* * *} \\
(4.62)\end{array}$ \\
\hline CAPEX & $\begin{array}{c}0.083 * \\
(1.94)\end{array}$ & $\begin{array}{l}-0.003 \\
(-0.07)\end{array}$ & $\begin{array}{c}1.282^{* * *} \\
(6.74)\end{array}$ & $\begin{array}{c}1.172 * * * \\
(6.46)\end{array}$ \\
\hline LEVERAGE & $\begin{array}{l}-0.028 \\
(-0.75)\end{array}$ & $\begin{array}{l}-0.009 \\
(-0.25)\end{array}$ & $\begin{array}{c}-0.291^{*} \\
(-1.72)\end{array}$ & $\begin{array}{l}-0.253 \\
(-1.57)\end{array}$ \\
\hline LOGSALES & $\begin{array}{c}0.152^{* * *} \\
(33.24)\end{array}$ & $\begin{array}{c}0.139 * * * \\
(31.48)\end{array}$ & $\begin{array}{c}0.204^{* * *} \\
(9.97)\end{array}$ & $\begin{array}{l}0.001 \\
(0.06)\end{array}$ \\
\hline Intercept & $\begin{array}{c}-1.013 * * * \\
(-16.99)\end{array}$ & $\begin{array}{c}-0.962 * * * \\
(-16.88)\end{array}$ & $\begin{array}{c}-0.770 * * * \\
(-2.89)\end{array}$ & $\begin{array}{c}0.577^{* *} \\
(2.23)\end{array}$ \\
\hline FF48 Industry & Yes & Yes & Yes & Yes \\
\hline Year Dummies & Yes & Yes & Yes & Yes \\
\hline Obs & 6783 & 6783 & 6783 & 6783 \\
\hline $\mathrm{R}^{\wedge} 2$ & $26.45 \%$ & $32.98 \%$ & $23.32 \%$ & $30.13 \%$ \\
\hline
\end{tabular}


Table 7. CSR, CSRLEVEL, and Firm Value

Results are from ordinary least squares (OLS) regression models. T-statistics are reported in parentheses. $* * *, * *, *$ denote statistical significance at the $1 \%, 5 \%$, and $10 \%$ levels, respectively.

\begin{tabular}{|c|c|c|c|c|}
\hline & Model 1 & Model 2 & Model 3 & Model 4 \\
\hline Dependent Variable & CSR & CSR & CSRLEVEL & CSRLEVEL \\
\hline CSR & & & & $\begin{array}{c}1.071 * * * \\
(43.10)\end{array}$ \\
\hline CSRLEVEL & & $\begin{array}{c}0.079 * * * \\
(43.10)\end{array}$ & & \\
\hline $\mathrm{Q}$ & $\begin{array}{c}0.025^{* * *} \\
(10.63)\end{array}$ & $\begin{array}{c}0.019 * * * \\
(8.27)\end{array}$ & $\begin{array}{c}0.081 * * * \\
(9.29)\end{array}$ & $\begin{array}{c}0.054 * * * \\
(6.45)\end{array}$ \\
\hline EXECDIR & & & & \\
\hline SHROWN & & & & \\
\hline Ln(CEOCOMP) & & & & \\
\hline ROA & $\begin{array}{c}-0.124 * * * \\
(-5.44)\end{array}$ & $\begin{array}{c}-0.163 * * * \\
(-7.47)\end{array}$ & $\begin{array}{c}0.494^{* * *} \\
(5.89)\end{array}$ & $\begin{array}{c}0.627^{* * *} \\
(7.81)\end{array}$ \\
\hline $\mathrm{RD}$ & $\begin{array}{c}0.001^{* * *} \\
(4.62)\end{array}$ & $\begin{array}{c}0.001^{* * *} \\
(4.49)\end{array}$ & $\begin{array}{l}0.001 \\
(1.13)\end{array}$ & $\begin{array}{c}-0.0002 \\
(-0.23)\end{array}$ \\
\hline$A D$ & $\begin{array}{l}0.062 \\
(1.41)\end{array}$ & $\begin{array}{l}0.044 \\
(1.04)\end{array}$ & $\begin{array}{c}0.226 \\
(1.4)\end{array}$ & $\begin{array}{l}0.160 \\
(1.04)\end{array}$ \\
\hline CAPEX & $\begin{array}{c}0.0002 * \\
(1.95)\end{array}$ & $\begin{array}{c}0.0001^{*} \\
(1.78)\end{array}$ & $\begin{array}{c}0.0003 \\
(0.86)\end{array}$ & $\begin{array}{c}0.00009 \\
(0.30)\end{array}$ \\
\hline LEVERAGE & $\begin{array}{c}-0.074 * * * \\
(-4.02)\end{array}$ & $\begin{array}{c}-0.060 * * * \\
(-3.41)\end{array}$ & $\begin{array}{c}-0.176 * * * \\
(-2.61)\end{array}$ & $\begin{array}{l}-0.097 \\
(-1.50)\end{array}$ \\
\hline LOGSALES & $\begin{array}{c}0.129 * * * \\
(60.33)\end{array}$ & $\begin{array}{c}0.125^{* * *} \\
(60.89)\end{array}$ & $\begin{array}{c}0.054 * * * \\
(6.91)\end{array}$ & $\begin{array}{c}-0.084 * * * \\
(-10.28)\end{array}$ \\
\hline Intercept & $\begin{array}{c}-0.631 * * * \\
(-22.41)\end{array}$ & $\begin{array}{c}-0.681 * * * \\
(-25.27)\end{array}$ & $\begin{array}{c}0.632^{* * *} \\
(6.12)\end{array}$ & $\begin{array}{c}1.308^{* * *} \\
(13.06)\end{array}$ \\
\hline FF48 Industry & Yes & Yes & Yes & Yes \\
\hline Year Dummies & Yes & Yes & Yes & Yes \\
\hline Obs & 20051 & 20051 & 20051 & 20051 \\
\hline $\mathrm{R}^{\wedge} 2$ & $22.38 \%$ & $28.99 \%$ & $18.27 \%$ & $25.22 \%$ \\
\hline
\end{tabular}


Table 8. Firm Value and CSR, CSRLEVEL

Results are from ordinary least squares (OLS) regression models. T-statistics are reported in parentheses. $* * *, * *, *$ denote statistical significance at the $1 \%, 5 \%$, and $10 \%$ levels, respectively.

\begin{tabular}{|c|c|c|}
\hline & Model 1 & Model 2 \\
\hline Dependent Variable & $\mathrm{Q}$ & $Q$ \\
\hline CSR & $\begin{array}{c}0.223 * * * \\
(10.63)\end{array}$ & \\
\hline CSRLEVEL & & $\begin{array}{c}0.053 * * * \\
(9.29)\end{array}$ \\
\hline EXECDIR & & \\
\hline SHROWN & & \\
\hline $\operatorname{Ln}(C E O C O M P)$ & & \\
\hline ROA & $\begin{array}{l}0.027 \\
(0.39)\end{array}$ & $\begin{array}{c}-0.027^{* * *} \\
(-0.40)\end{array}$ \\
\hline $\mathrm{RD}$ & $\begin{array}{c}-0.002 * \\
(-1.77)\end{array}$ & $\begin{array}{l}-0.001 \\
(-1.50)\end{array}$ \\
\hline$A D$ & $\begin{array}{c}0.928 * * * \\
(7.10)\end{array}$ & $\begin{array}{c}0.931 * * * \\
(7.12)\end{array}$ \\
\hline CAPEX & $\begin{array}{c}-0.00002 * \\
(-0.07)\end{array}$ & $\begin{array}{c}0.000006 \\
(0.02)\end{array}$ \\
\hline LEVERAGE & $\begin{array}{c}-0.185^{* * *} \\
(-3.38)\end{array}$ & $\begin{array}{c}-0.192 * * * \\
(-3.51)\end{array}$ \\
\hline LOGSALES & $\begin{array}{c}-0.138 * * * \\
(-20.08)\end{array}$ & $\begin{array}{c}-0.112 * * * \\
(-17.67)\end{array}$ \\
\hline Intercept & $\begin{array}{c}2.830 * * * \\
(34.33)\end{array}$ & $\begin{array}{c}2.660 * * * \\
(32.51)\end{array}$ \\
\hline FF48 Industry & Yes & Yes \\
\hline Year Dummies & Yes & Yes \\
\hline Obs & 20051 & 20051 \\
\hline $\mathrm{R}^{\wedge} 2$ & $21.31 \%$ & $21.20 \%$ \\
\hline
\end{tabular}




\section{Appendix 1: Variable Definitions and measures}

Variable Definition

$\underline{\text { CSR }}$

CSR A dummy variable $=1$ if a firm has engaged in corporate social responsibility.

CSRLEVEL KLD scores (total strengths minus total concerns) aggregated across the categories of community, diversity, employee relations, environment, human rights, and product.

\section{CEO Power}

CPS The percentage of the total compensation to the top five executives that goes to the CEO.

CEOTENURE The number of years since becoming CEO.

DUALITY A dummy equals 1 if the CEO also chairs the board and 0 otherwise.

\section{Firm Performance}

Q The market value of equity plus the book value of assets minus the sum of book value of common equity and deferred taxes, all divided by the book value of assets.

\section{CEO Characteristics}

CEOCOMP CEO total compensation (tdc1 from EXECUCOMP).

EXECDIR A dummy variable $=1$ if a CEO is also a board member and 0 otherwise.

SHROWN The number of shares owned by the CEO divided by the company's total shares outstanding.

\section{Firm Characteristics}

R\&D Total research and development expenses divided by total sales.

AD Total advertising expenses divided by total sales

Leverage Total long-term debt divided by total assets

CAPEX Total capital expenditure divided by total assets

LOGSALES The natural logarithm of total sales

ROA Return on assets: Net income before extraordinary items and discontinued operations divided by total assets. 